\title{
ПОРІВНЯЛЬНИЙ АНАЛІЗ КАРДІОПРОТЕКТОРНИХ ВЛАСТИВОСТЕЙ КОРВІТИНУ ТА СУХОГО ЕКСТРАКТУ 3 ХОСТИ ЛАНЦЕТОЛИСТОЇ ЛИСТЯ ЗА УМОВ АДРЕНАЛІНОВОГО УШКОДЖЕННЯ СЕРЦЯ
}

Вступ. У сучасних умовах психоемоційний стрес ускладнює перебіг і прогноз основних захворювань серцево-судинної системи (ішемічної хвороби серця, інсраркту міокарда, гіпертонічної хвороби, атеросклерозу) та може призвести до розвитку некротичного ушкодження міокарда. Дослідження, які проводять в останні роки фрармакологи, фрармацевти і медики, спрямовані на пошук нових рослинних засобів із кардіопротекторними властивостями з більшою ефективністю та меншою токсичністю порівняно з існуючими на сьогодні на фрармацевтичному ринку препаратами.

Мета дослідження - вивчити мембранопротекторні властивості сухого екстракту з хости ланцетолистої листя та показники фрункціонування серцевого м'яза на моделі токсичного ураження серця адреналіном.

Методи дослідження. Експерименти проведено на шестимісячних 42-х білих щурах-самцях масою 180-200 г. Некротичне ушкодження міокарда моделювали шляхом одноразового внутрішньом'язового введення 0,18 \% розчину адреналіну гідротартрату з розрахунку 0,5 мг/кг. 3 метою корекції щодня протягом експерименту вводили сухий екстракт з хости ланцетолистої листя в дозі 100 мг/кг маси тіла та корвітин у дозі 42 мг/кг. Дослідження виконували через 24 та 48 год після введення адреналіну. Записували і проводили аналіз електрокардіограм, у сироватці крові та серці визначали активність аспартатамінотрансфрерази і креатинфоссрокінази.

Результати й обговорення. Активність аспартатамінотрансферази і креатинфросфрокінази у сироватці крові щурів, яким вводили адреналін, підвищувалася в усі терміни експерименту. Активність креатинсроссрокінази в сироватці крові тварин після введення адреналіну збільшувалася: через 24 год -у 2,2 раза, через 48 год - у 2,5 раза. У серці щурів спостерігали зворотну тенденцію до зниження цих показників. Через 24 год після введення адреналіну позитивний вплив на активність ензимів мав корвітин. У кінці експерименту ефективними виявились обидва коригувальних чинники. На електрокардіограмах підтверджено розвиток міокардіодистроорії в щурів, які отримали токсичну дозу адреналіну. До кінця експерименту як екстракт, так і корвітин проявили позитивний вплив на показники електрокардіограми у тварин, що підтвердило їх кардіопротекторні властивості.

Висновки. Кардіотоксична доза адреналіну призводить до цитолізу кардіоцитів та зміни проникності плазматичних мембран, на що вказують підвищення активності аспартатамінотрансферази і креатинфоосфокінази у сироватці крові та ї̈ зниження в серці. Сухий екстракт з хости ланцетолистої листя та корвітин мають виражений протекторний вплив на активність ензимів. Екстракт і корвітин, введені на тлі адреналінового ушкодження серця, зменшують збудливість синусового вузла та сповільнюють проведення імпульсів передсердями і шлуночками.

КЛЮЧОВІ СЛОВА: адреналін; сухий екстракт з хости ланцетолистої листя; корвітин; білі щури.

ВСТУП. Протягом останнього десятиліття, незважаючи на постійний пошук нових і вдосконалення існуючих методів лікування, патологія серця, що ускладнюється некрозом міокарда, набуває все більшого розповсюдження [1, 2].

Статистичні дані свідчать про зростання частки патології серця в загальній структурі захворюваності та смертності. В Україні хвороби системи кровообігу посідають перше місце та (ㅇ О. С. Линда, В. Є. Пелих, Л. С. Фіра, О.В.Денефіль, 2019. становлять 25,9 \%. Фактично в кожного четвертого пацієнта країни діагностують серцево-судинну патологію $[3,4]$. Результати сучасних досліджень дають підстави стверджувати, що в генезі ішемічної хвороби серця важливим моментом $€$ надмірні психоемоційні навантаження. Різке збільшення темпів життя, автоматизація всіх сорер діяльності людини, урбанізація призводять до появи невідреагованих емоцій. Саме психоемоційний стрес часто передує розвитку 
гіпертонічного кризу, інфраркту міокарда, раптової серцевої смерті. Стрес ускладнює перебіг і прогноз основних захворювань серцево-судинної системи та може призвести до розвитку некротичного ушкодження міокарда $[5,6]$.

За експериментальну модель часто обирають методику одноразового внутрішньом'язового введення великої дози розчину катехоламінів а саме адреналіну $[7,8]$. Цю модель широко використовують для дослідження некротичних процесів у міокарді та протекторної дії різноманітних кардіотропних препаратів [9].

В останні десятиліття науковий пошук фрармакологів, фрармацевтів і клініцистів спрямований на створення та впровадження в медичну практику засобів, що успішно усувають порушення клітинного метаболізму, іонного гомеостазу і функцій мембран кардіоміоцитів, попереджуючи розвиток необоротних процесів у міокарді [10].

3 огляду на це, в комплексній терапії захворювань найбільш широко застосовують лікарські засоби 3 антиоксидантними та мембранопротекторними властивостями, зокрема фрлавоноїдної структури [11], пошук яких серед рослинної сировини триває. Сучасні дослідження спрямовані на пошук таких засобів із більшою есрективністю та меншою токсичністю порівняно з існуючими на фрармацевтичному ринку лікарськими препаратами.

Нашу увагу привернула така рослина, як хоста ланцетолиста, листя якої містить ряд біологічно активних речовин, а саме: карбонові кислоти, гідроксикоричні кислоти, поліфеноли та фрлавоноїди. Ідентифріковано кверцетин, кемпорерол, гіперозид та астрагалін. Дані біологічно активні речовини забезпечують прояв антиоксидантного ефекту та, як результат, виражені мембранопротекторні властивості $[12,13]$.

3 огляду на це, метою дослідження було вивчити мембранопротекторні властивості сухого екстракту 3 хости ланцетолистої листя та показники фрункціонування серцевого м'яза на моделі токсичного ураження серця адреналіном.

МЕТОДИ ДОСЛІДЖЕННЯ. Експерименти проведено на шестимісячних 42-х білих щурахсамцях масою 180-200 г. Некротичне ушкодження міокарда моделювали шляхом одноразового внутрішньом'язового введення тваринам 0,18\% розчину адреналіну гідротартрату (ЗАТ “Фармацевтична фрірма "Дарниця", м. Київ, Україна) 3 розрахунку 0,5 мг/кг за методикою О. О. Маркової. Така доза адреналіну викликає некротичне ушкодження міокарда при мінімальній смертності тварин. Цю модель використовують для дослідження протекторної дії різноманітних кардіо- тропних препаратів при некротичному ушкодженні серця [14].

Сухий екстракт з хости ланцетолистої листя (СЕХЛ) тварини отримували внутрішньошлунково в дозі 100 мг/кг маси тіла, розчин готували шляхом розведення 20 мг (0,02 г) екстракту в 1 мл води.

Як препарат порівняння використовували корвітин (комплекс кверцетину з полівідоном, фрлакони по 0,5 г виробництва ЗАТ НВЦ “Борщагівський хіміко-фрармацевтичний завод”, м. Київ, Україна) - напівсинтетичний лікарський засіб із антиоксидантною активністю, який вводили внутрішньовенно (у хвостову вену). Значення дози препарату порівняння обирали, спираючись на інструкцію до застосування та використовуючи коефіцієнти видової чутливості Ю. Р. Риболовлєва і його метод перерахунку дози для людини на дозу для щура [15]. Умовно-терапевтична доза для щура становить 42 мг/кг [16] (фрлакон 3 корвітином розчиняли в 125 мл фрізіологічного розчину $\mathrm{NaCl}$ і вводили по 0,2 мл у хвостову вену).

Для проведення відповідних досліджень щурів поділили на чотири групи: 1-ша-контрольні тварини (інтактний контроль); 2-га - щури, яким вводили одноразово адреналін; 3-тя - тварини, яким вводили адреналін та СЕХЛ; 4-та щури, яким вводили адреналін та корвітин. Препарати для корекції вводили щодня протягом експерименту.

Дослідження виконували через 24 та 48 год від початку введення адреналіну. За допомогою пристрою "CardoiLab" (м. Харків, Україна) записували електрокардіограми (ЕКГ) під наркозом (40 мг·кг ${ }^{-1}$ маси тіла тварини), який вводили внутрішньочеревно. Записували й аналізували 100 послідовно розташованих кардіоінтервалів R-R. За допомогою комп'ютерної програми розраховували тривалість інтервалів, тривалість та амплітуду зубців у стандартних і підсилених відведеннях. Для аналізу брали показники II стандартного відведення, а також I і III стандартних відведень. Аналізували амплітуду зубця Т і положення сегмента S-T відносно ізолінії. Для оцінки сили серцевих скорочень використовували систолічний показник (СП). Величина цього показника перебувала в оберненій залежності від скоротливої здатності міокарда.

Тварин піддавали евтаназії під тіопенталовим наркозом. У сироватці крові та серці визначали активність аспартатамінотрансферази (АсАТ) [17] і креатинфросорокінази (КФК) [17].

Усі експерименти проводили в спеціально відведеному приміщенні при температурі 18$22{ }^{\circ} \mathrm{C}$, відносній вологості 40-60 \% і освітленості 250 лк. При цьому дотримувались усіх правил щодо роботи з хребетними тваринами [18]. 
Статистичну обробку цифррових даних виконано за допомогою програмного забезпечення Excel ("Microsoft", СШA) i STATISTICA 6.0 ("Statsoft", США). Достовірність різниці значень між незалежними кількісними величинами встановлювали при нормальному розподілі за критерієм Стьюдента, в інших випадках - за допомогою непараметричних методів Вілкоксона [19] для зв'язаних вибірок. Зміни вважали вірогідними при $\mathrm{p} \leq 0,05$.

РЕЗУЛЬТАТИЙ ОБГОВОРЕННЯ. НОрМОЛЬНе срункціонування органів залежить від стану цитоплазматичних мембран клітин, зміна структури та фрункції яких порушує їх бар'єрну здатність i $є$ причиною виникнення патологічних процесів. Відомо, що зростання швидкості оновлення ензимів або їх індукування та ушкодження клітин призводять до підвищення їх активності в сироватці крові. Рівень активності органоспецисрічних ензимів корелює зі ступенем вираження патологічного процесу [20].

Для оцінки тканинно-деструктивних процесів при ураженні тварин адреналіном було досліджено активність у сироватці крові та міокарді таких ензимів, як аспартатамінотрансфераза і креатиноросфокіназа. Аспартатамінотрансореразу широко використовують у медичній практиці для лабораторної діагностики уражень міокарда. Ензим синтезується внутрішньоклітинно, і в нормі лише невелика його частина потрапляє в кров. При ушкодженні міокарда, в результаті цитолізу, в крові реєструють значну активність AcAT.

Активність АсАТ у сироватці крові щурів, яким вводили адреналін, підвищувалася в усі терміни дослідження (табл. 1). Після введення адреналіну вона зросла: у термін 24 год - на 49,8 \%, у термін 48 год - на 74,5\% порівняно з інтактними тваринами. У тварин, які отримували СЕХЛ, цей показник був нижчим від такого в нелікованих щурів: на 18,9 \% - через 24 год, на 24,4 \% - у кінці експерименту $(p \leq 0,05)$. Більш ефрективним виявився корвітин. До кінця дослідження після його застосування активність АсАТ у сироватці крові щурів, яким вводили адреналін, зменшилася на $61,8 \%(p \leq 0,05)$.

У серці щурів, яким вводили адреналін, відмічали прогресуюче зниження активності АсАТ у всі терміни дослідження. У термін 48 год після введення адреналіну показник був нижчим від норми на 31,25 \%. Після введення в уражений організм СЕХЛ спостерігали підвищення активності досліджуваного ензиму, але достовірних змін не відзначено. Застосування корвітину призвело до вірогідного підвищення $(p \leq 0,05)$ активності АсAТ у серці щурів після ураження.

Доцільним, на нашу думку, було також дослідити активність креатинфоосфокінази - ензиму, що локалізується в кардіоміоцитах та каталізує реакцію перенесення залишку фросфатної кислоти з АТФ на креатин з утворенням креатинфоссрату, який є енергетичним субстратом для серця [7].

Відмічено значне зростання активності КФК у сироватці крові тварин після введення адреналіну. Через 24 год від початку експерименту вона збільшилась у 2,2 раза порівняно з контролем. Через 48 год з моменту потрапляння в організм адреналіну активність КФК підвищилась у 2,5 раза (табл. 2).

Таблиця 1 - Активність аспартатамінотрансферази в сироватці крові (мкмоль/(л·год)) та міокарді

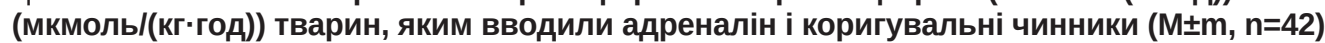

\begin{tabular}{|c|c|c|c|c|}
\hline \multirow{3}{*}{ Група тварин } & \multicolumn{2}{|c|}{ Сироватка крові } & \multicolumn{2}{|c|}{ Серце } \\
\hline & \multicolumn{4}{|c|}{ 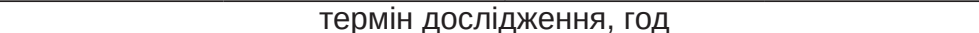 } \\
\hline & 24 & 48 & 24 & 48 \\
\hline Інтактний контроль & \multicolumn{2}{|c|}{$2,75 \pm 0,19$} & \multicolumn{2}{|c|}{$3,20 \pm 0,17$} \\
\hline Адреналін & $4,12 \pm 0,39^{\star}$ & $4,80 \pm 0,39 *$ & $2,55 \pm 0,14^{*}$ & $2,20 \pm 0,11^{*}$ \\
\hline Адреналін+СЕХЛ & $3,60 \pm 0,29$ & $3,49 \pm 0,19^{\star \star}$ & $2,75 \pm 0,14$ & $2,45 \pm 0,14$ \\
\hline Адреналін+корвітин & $3,45 \pm 0,19$ & $3,10 \pm 0,18^{\star \star}$ & $3,12 \pm 0,10^{\star \star}$ & $2,85 \pm 0,16^{\star \star}$ \\
\hline
\end{tabular}

Примітка. Тут і в таблицях 2-5: * - достовірні зміни між інтактними тваринами та щурами, яким вводили адреналін $(p \leq 0,05) ; * *$ достовірні зміни між щурами, яким вводили адреналін, та лікованими тваринами $(p \leq 0,05)$.

Таблиця 2 - Активність креатинфроссрокінази в сироватці крові (мкат/л) та міокарді (мкат/кг) тварин, уражених адреналіном, і після застосування коригувальних чинників ( $\mathrm{M} \pm \mathrm{m}, \mathrm{n}=42)$

\begin{tabular}{|c|c|c|c|c|}
\hline \multirow{3}{*}{ Група тварин } & \multicolumn{2}{|c|}{ Сироватка крові } & \multicolumn{2}{|c|}{ Серце } \\
\hline & \multicolumn{4}{|c|}{ термін дослідження, год } \\
\hline & 24 & 48 & 24 & 48 \\
\hline Інтактний контроль & \multicolumn{2}{|c|}{$8,25 \pm 0,52$} & \multicolumn{2}{|c|}{$9,50 \pm 0,47$} \\
\hline Адреналін & $18,50 \pm 1,34^{*}$ & $20,75 \pm 1,43^{\star}$ & $6,20 \pm 0,53^{\star}$ & $4,70 \pm 0,40 *$ \\
\hline Адреналін+СЕХЛ & $14,25 \pm 0,89^{\star \star}$ & $13,00 \pm 0,99^{\star \star}$ & $7,25 \pm 0,34$ & $8,60 \pm 0,45^{\star \star}$ \\
\hline Адреналін+корвітин & $12,45 \pm 0,90^{\star \star}$ & $11,50 \pm 0,65^{\text {** }}$ & $8,60 \pm 0,59^{\star *}$ & $9,05 \pm 0,58^{\star \star}$ \\
\hline
\end{tabular}


Обидва коригувальних чинники призвели до зменшення активності КФК у сироватці крові (екстракт знизив досліджуваний показник в 1,6 раза, корвітин - в 1,8 раза відносно групи уражених тварин).

Активність КФК у серці щурів, яким вводили адреналін, зменшувалась у всі терміни дослідження. Максимально низькою вона була в термін 48 год від моменту ушкодження (у 2 рази меншою від норми).

Через 24 год після ураження до достовірного $(p \leq 0,05)$ підвищення даного показника в досліджуваній тканині призвело використання корвітину (активність КФК зросла в 1,4 раза). У цей термін після застосування екстракту спостерігали тенденцію до збільшення активності ензиму, достовірних змін не відмічено. У кінці експерименту ефективний вплив на даний показник проявили обидва коригувальних чинники.

Отже, ушкодження серця щурів токсичними дозами адреналіну призводить до цитолізу кар- діоцитів та зміни проникності плазматичних мембран, на що вказують підвищення активності АсАТ і КФК у сироватці крові та зниження її в серці.

Ми дослідили показники ЕКГ у щурів, уражених підвищеними дозами адреналіну, та після застосування СЕХЛ і корвітину (табл. 3-5).

При аналізі ЕКГ у тварин, яким вводили адреналін, виявлено, що через 24 год після його введення достовірно $(p \leq 0,05)$ зменшувалась частота серцевих скорочень (ЧСС). Спостерігали збільшення тривалості інтервалу R-R на 7,5 \%, Q-Tc - на 3,5 \%, амплітуди зубця R - y 2,4 раза. Тільки у III стандартному відведенні амплітуда зубця Т зменшилась на 69,7 \%.

Через 48 год після введення адреналіну на ЕКГ щурів виявлено зниження ЧСС на $12,4 \%$, СП - на 25,4 \%. Відмічено збільшення тривалості інтервалу R-R на 14,2 \%, P-Q - на $62,3 \%$, Q-Tc - на 6,8 \%, амплітуди зубця R - на $91,3 \%$

Таблиця 3 - Зміни на електрокардіограмах у тварин при адреналіновому ушкодженні серця

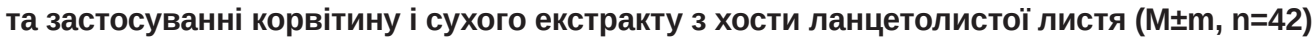

\begin{tabular}{|c|c|c|c|}
\hline \multirow{2}{*}{ Група тварин } & \multicolumn{3}{|c|}{ Показник } \\
\hline & पCC, $X^{-1}$ & інтервал R-R, мc & СП, \% \\
\hline Інтактний контроль & $500,67 \pm 9,13$ & $120,00 \pm 2,19$ & $65,00 \pm 5,57$ \\
\hline Адреналін 24 год & $465,50 \pm 3,94^{*}$ & $129,00 \pm 1,12^{*}$ & $52,00 \pm 2,48$ \\
\hline Адреналін 48 год & $468,67 \pm 5,25^{*}$ & $137,00 \pm 1,61^{*}$ & $48,50 \pm 0,56^{*}$ \\
\hline Адреналін 24 год+корвітин & $451,33 \pm 14,25^{*}$ & $133,67 \pm 4,05^{\star}$ & $58,67 \pm 1,94$ \\
\hline Адреналін 48 год+корвітин & $417,00 \pm 3,10^{\star},{ }^{* \star}$ & $144,00 \pm 1,03^{\star}$, ,* & $65,00 \pm 3,14^{* *}$ \\
\hline Адреналін 24 год+СЕХЛ & $468,33 \pm 20,28$ & $129,33 \pm 5,33$ & $51,33 \pm 2,11^{*}$ \\
\hline Адреналін 48 год+СЕХЛ & $388,80 \pm 23,13^{*}, * *$ & $156,40 \pm 8,97^{*}, * \star$ & $46,00 \pm 3,11^{*}$ \\
\hline
\end{tabular}

Таблиця 4 - Зміни тривалості й амплітуди зубців на електрокардіограмах у тварин при адреналіновому ушкодженні серця та застосуванні корвітину і сухого екстракту

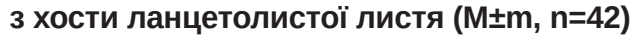

\begin{tabular}{|c|c|c|c|c|}
\hline \multirow{2}{*}{ Група тварин } & \multicolumn{4}{|c|}{ Показник } \\
\hline & зубець P, мс & зубець R, мB & зубець $T_{\|}, \mathrm{MB}$ & зубець $T_{\mu}, \mathrm{MB}$ \\
\hline Інтактний контроль & $11,000 \pm 1,840$ & $0,350 \pm 0,070$ & 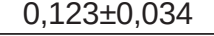 & $0,127 \pm 0,008$ \\
\hline Адреналін 24 год & $9,330 \pm 1,120$ & $0,790 \pm 0,050^{*}$ & $0,073 \pm 0,009$ & $0,038 \pm 0,013^{*}$ \\
\hline Адреналін 48 год & $10,330 \pm 2,090$ & $0,660 \pm 0,050^{*}$ & $0,057 \pm 0,025$ & $0,072 \pm 0,028$ \\
\hline Адреналін 24 год+корвітин & $15,330 \pm 0,840$ ** & $0,640 \pm 0,040 *, \star \star$ & $0,095 \pm 0,022$ & $0,055 \pm 0,029 *$ \\
\hline Адреналін 48 год+корвітин & $16,000 \pm 1,150 *, * *$ & $0,680 \pm 0,050^{\star}$ & $0,102 \pm 0,010$ & $0,125 \pm 0,022$ \\
\hline Адреналін 24 год+СЕХЛ & $12,330 \pm 1,500$ & $0,690 \pm 0,040^{\star}$ & $0,107 \pm 0,011^{\star \star}$ & $0,075 \pm 0,012^{*}$ \\
\hline Адреналін 48 год+СЕХЛ & $13,600 \pm 2,480$ & $0,950 \pm 0,100 *, * \star$ & $0,174 \pm 0,029^{\star \star}$ & $0,092 \pm 0,036$ \\
\hline
\end{tabular}

Таблиця 5 - Зміни тривалості інтервалів на електрокардіограмах у тварин при адреналіновому ушкодженні серця та застосуванні корвітину і сухого екстракту 3 хости ланцетолистої листя (M $\pm m, n=42)$

\begin{tabular}{|c|c|c|c|}
\hline \multirow{2}{*}{ Група тварин } & \multicolumn{3}{|c|}{ Показник } \\
\hline & інтервал P-Q, мс & інтервал Q-Т, мс & інтервал Q-Тс, мс \\
\hline Інтактний контроль & $28,33 \pm 4,45$ & $77,67 \pm 6,05$ & $138,67 \pm 1,28$ \\
\hline Адреналін 24 год & $39,67 \pm 3,16$ & $67,33 \pm 3,08$ & $143,50 \pm 0,56^{*}$ \\
\hline Адреналін 48 год & $46,00 \pm 0,89^{*}$ & $66,67 \pm 0,84$ & $148,17 \pm 1,01^{*}$ \\
\hline Адреналін 24 год+корвітин & $42,66 \pm 1,84^{*}$ & $78,00 \pm 1,37^{* *}$ & $146,50 \pm 2,23^{*}$ \\
\hline Адреналін 48 год+корвітин & $34,67 \pm 3,39 * *$ & $93,33 \pm 4,12^{\star \star}$ & $152,00 \pm 0,52^{\star}$, ,* \\
\hline Адреналін 24 год+СЕХЛ & $42,33 \pm 2,98 *$ & $66,00 \pm 0,52$ & $143,67 \pm 3,02$ \\
\hline Адреналін 48 гоД+СЕХЛ & $50,00 \pm 3,69 *$ & $71,20 \pm 4,32$ & $158,00 \pm 4,61^{\star}, \star \star$ \\
\hline
\end{tabular}


Отримані дані свідчать про те, що через 48 год, порівняно $з$ попереднім терміном дослідження, поглиблюються виявлені на ЕКГ зміни.

Виявлені на ЕКГ зміни ЧСС можуть вказувати на те, що при екзогенному введенні адреналіну зменшується ендогенний адренергічний вплив на серце. Очевидно, в цьому випадку через 24 та 48 год збільшується парасимпатичний вплив на даний орган. Отриманий результат можна розцінювати як компенсаторну реакцію, направлену на киснезберігальний ефект, менше споживання кисню за умов гіпоксії, що виникла при ушкодженні серця адреналіном.

За цих умов зберігається позитивний інотропний ефрект, оскільки зменшення СП вказує на зростання скоротливої здатності міокарда. Отримані дані можуть бути зумовлені впливом адреналіну на постсинаптичні а1-адренорецептори. Останні локалізовані в серці та відіграють важливу роль у реалізації інотропного ефекту, не впливаючи на чСС [21].

Зміни, які пов'язані зі збільшенням проведення імпульсів передсердями, можуть вказувати на зменшення чСС та розвиток гіпокаліємії. Зростання тривалості інтервалу Q-Тс, очевидно, зумовлене зміною проникності іонних каналів для калію (зменшення потоку) і кальцію (збільшення входу) [22]. Такі порушення кальцієвого гомеостазу призводять до гіпокальціємії, накопичення кальцію в міофрібрилах. Це може викликати контрактурні зміни, некроз кардіоміоцитів, розвиток дистрофії міокарда. Зменшення амплітуди зубця Т може свідчити про розвиток дистрофрічних змін у серці. Оскільки це відмічено тільки у III стандартному відведенні, то може вказувати на розвиток ішемії в задній стінці лівого шлуночка [23]. Враховуючи анатомічні особливості коронарного кровообігу в щурів, можемо вважати це нормою для них.

Зміни амплітуди зубця R можуть зумовити збільшення сили скорочення лівого шлуночка. Через 48 год амплітуда зубця R почала відновлюватися, що підтвердило зменшення кардіотоксичного впливу адреналіну.

Через 24 год після введення адреналіну та застосування 3 метою корекції корвітину виявлено достовірне зменшення чСС на 9,8 \% і амплітуди зубця Т у III відведенні на 56,6 \%. Одночасно відмічено підвищення ряду показників. Так, тривалість інтервалу R-R зросла на $11,4 \%$, P-Q - на 50,6 \%, Q-Tc - на 5,6\%. Спостерігали збільшення амплітуди зубця R на $85,1 \%$.

Через 48 год після введення адреналіну та застосування корвітину виявлено достовірне $(p \leq 0,05)$ зменшення ЧСС на 16,7 \% і підвищення ряду показників. Так, тривалість інтервалу R-R зросла на 20 \%, Q-Тc - на 9,6\%. Спостерігали збільшення тривалості та амплітуди зубців: тривалість зубця Р зросла на 45,4 \%, амплітуда зубця R - на 95,2 \%, комплекс QRS подовжився на 66,2 \%. Через 48 год, порівняно з попереднім терміном дослідження, чСС зменшилася на 7,6 \%, тривалість інтервалу R-R збільшилася на 7,7 \%, Q-T - на 19,7 \%, Q-Tс - на 3,7 \%, комплексу QRS - на 73,5 \%.

При порівнянні отриманих показників із показниками групи тварин без корекції виявлено позитивний вплив корвітину.

Порівняно з контролем не виявлено достовірного впливу адреналіну на $\alpha 1$-адренорецептори, оскільки відновлювався СП і був вірогідно $(p \leq 0,05)$ вищим, ніж показник ЕКГ у тварин без корекції. Відмічено поступове відновлення амплітуди зубця Т у III відведенні до показника щурів інтактного контролю. Зміни тривалості інтервалу P-Q через 48 год були меншими при корекції на 24,6 \% і не відрізнялися від контролю. Значення Q-Tс через 24 год достовірно не відрізнялися, через 48 год зросли при застосуванні корвітину на 34 \%. Оскільки цей показник залежить від чСС, то виявлені зміни можна пояснити зниженням останнього.

Зі збільшенням тривалості інтервалу R-R, яке свідчить про сповільнення процесів деі реполяризації в кардіоміоцитах, пов'язане зростання тривалості зубця Р (через 24 год - на 64,3 \%, через 48 год - на 54,8 \%) та комплексу QRS (через 48 год - на 66,2 \%). Це вказує на подовження процесу деполяризації як передсердями, так і шлуночками в серці тварин. Зростання амплітуди зубців свідчить про збільшення скоротливої здатності кардіоміоцитів, що, очевидно, пов'язано з підвищенням енергетичного забезпечення кардіоміоцитів завдяки антиоксидантному впливу корвітину та поліпшенню коронарного кровообігу.

Аналогічні зміни на ЕКГ після введення адреналіну та застосування з метою корекції корвітину спостерігали й інші автори. Під час дослідів вони відмічали зменшення ЧСС, збільшення тривалості інтервалів P-Q, Q-T, Q-Tc, зубця $\mathrm{P}$, амплітуди зубців P і T, положення сегмента S-T відносно ізолінії. Кверцетин, який $€$ основою корвітину, вводили протягом 7-ми днів у дозі 200 мг/кг. Препарат спричинив зміни, аналогічні нашим, а саме нормалізацію чСС, тривалості та амплітуди зубця Р, тривалості інтервалу Q-Tc і зубця T, положення сегмента S-T щодо ізолінії [1].

Через 24 год після введення адреналіну та застосування з метою корекції екстракту виявлено достовірне зменшення СП на $21 \%$, амплітуди зубця Т у III відведенні - на 40,8 \%, збіль- 
шення тривалості інтервалу P-Q на 49,4 \%, амплітуди зубця R - на 99 \%. Через 48 год після введення адреналіну та використання екстракту відзначено достовірне зниження чСС на 22,3\%, СП - на 29,2 \%, зростання тривалості інтервалу R-R на 30,3\%, P-Q - на 76,5\%, Q-Tс-на 13,9\%, амплітуди зубця $\mathrm{R}$ - y 2,7 раза.

Отже, через 24 год після введення адреналіну та застосування з метою корекції екстракту відмічено збільшення скоротливої здатності міокарда шлуночків, що може вказувати на зростання енергетичного забезпечення кардіоміоцитів. Водночас зберігалась ішемія задніх відділів лівого шлуночка, були ЕКГ-ознаки змін іонів калію у крові.

Через 48 год після введення адреналіну та застосування екстракту з хости ланцетолистої листя відмічено зменшення симпатичного впливу на серце, зростання скоротливої здатності міокарда. Ці зміни вказували на покращення енергетичного забезпечення серця. Однак зберігалися зміни проникності іонних каналів для калію (зменшення потоку) і кальцію (збільшення входу). При порівнянні показників через 48 і 24 год виявлено тільки зміни провідності, пов'язані зі зниженням чСС.

Якщо розглядати ефрективність дії СЕХЛ, то через 24 год у тварин, яким вводили екстракт, порівняно $з$ тими, яким не проводили корекції, виявлено меншу на 45,9 \% тривалість комплекcy QRS та більшу на 45,4 \% амплітуду зубця T у II стандартному відведенні. Через 48 год відзначено зменшення ЧСС на 11,4 \%, збільшення тривалості інтервалу R-R на 14,1 \%, Q-Tc - на 6,6 \%, амплітуди зубця R - на 42,9 \%, зубця T у II стандартному відведенні-у 3,1 раза. Отримані дані вказували на пришвидшення процесів деполяризації шлуночками через 24 год. Через 48 год виявлено зменшення збудливості синусового вузла, що спричинювало зниження чСС і подовження інтервалів, посилення процесів де- та реполяризації шлуночками.

При порівнянні дії СЕХЛ і корвітину через 24 год після введення адреналіну відмічено тільки достовірне зниження СП на 12,5\%. Через 48 год тривалість інтервалу P-Q збільшилася на 44,2 \%, амплітуда зубця R - на 40,1 \% і зубця T у II стандартному відведенні - на 71,1 \%. Відзначено зменшення тривалості комплексу QRS на $50,1 \%$, інтервалу Q-Т - на 23,7 \%, СП - на $29,2 \%$.

Отримані дані вказували на покращення скоротливості міокарда під впливом СЕХЛ. При застосуванні корвітину підвищувалось енергетичне забезпечення кардіоміоцитів завдяки антиоксидантному впливу та поліпшенню кровообігу. Можливо, що й екстракт з хости ланцетолис- тої листя має такі самі властивості за рахунок антиоксидантного ефекту групи біологічно активних речовин, які $є$ в цій рослині. Подовження інтервалів P-Q i Q-T на ЕКГ може бути пов'язане зі зменшенням чСС, порушенням електролітного балансу, зокрема кальцієво-магнієвого, що спостерігають при впливі адреналіну не тільки на серце, але й на ендокринні залози.

Отже, на ЕКГ підтверджено розвиток міокардіодистросрії в щурів, які отримали токсичну дозу адреналіну. Введення сухого екстракту з хости ланцетолистої листя при розвитку адреналінової міокардіодистрофії сприяло зростанню деполяризації шлуночків, збільшенню скоротливої здатності серця. Порівняно з тваринами з адреналіновим ушкодженням серця, яким не проводили корекції, виявлено покращення проведення біоелектричних потенціалів шлуночками, що вказувало на зменшення проявів гіпоксії, очевидно, завдяки зростанню енергозабезпечення серця.

При порівнянні ефрективності впливу СЕХЛ 3 корвітином через 24 і 48 год після введення адреналіну відзначено покращення скоротливої здатності міокарда, сповільнення проведення імпульсів передсердями та шлуночками. Екстракт і корвітин, введені на тлі дії адреналіну, зменшували збудливість синусового вузла та сповільнювали проведення імпульсів передсердями і шлуночками.

Проведені дослідження підтверджують кардіопротекторний есрект досліджуваного екстракту з хости ланцетолистої листя, що робить даний орітозасіб перспективним для подальших досліджень.

ВИСНОВКИ. 1. Кардіотоксична доза адреналіну призводить до цитолізу кардіоцитів та зміни проникності плазматичних мембран, нащо вказують підвищення активності аспартатамінотрансорерази і креатинороссокінази у сироватці крові та її зниження в серці. У сироватці крові при розвитку адреналінової міокардіодистрофії екстракт з хости ланцетолистої листя та корвітин мають однаково виражений протекторний вплив на аспартатамінотрансферазу тільки через 48 год після введення адреналіну. В серці тварин ефект від введення корвітину проявляється через 24 та 48 год. Активність креатинфроссрокінази нормалізується при введенні обох коригувальних чинників однаково в усі досліджувані терміни.

2. На електрокардіограмах підтверджено розвиток міокардіодистросрії в щурів, які отримали токсичну дозу адреналіну. Введення сухого екстракту з хости ланцетолистої листя сприяє зростанню деполяризації шлуночків, збільшенню 
скоротливої здатності серця, покращенню проведення біоелектричних потенціалів шлуночками. При застосуванні екстракту та корвітину через 24 і 48 год після введення адреналіну поліпшується скоротлива здатність міокарда, сповільнюється проведення імпульсів передсердями та шлуночками. Сухий екстракт 3 хости ланцетолистої листя і корвітин, введені на тлі ураження серця щурів токсичними дозами адре- наліну, зменшують збудливість синусового вузла та сповільнюють проведення імпульсів передсердями і шлуночками.

Перспективи подальших досліджень. Отримані результати вказують на доцільність подальшого вивчення кардіопротекторних властивостей сухого екстракту з хости ланцетолистої листя 3 метою створення на його основі нового лікарського рослинного засобу.

\section{СПИСОК ЛІТЕРАТУРИ}

1. Мусієнко А. М. Зміни показників електрокардіограм при адреналіново-кальцієвій моделі ураження серця щурів-самців та застосуванні з метою корекції кверцетину / А. М. Мусієнко, О.В.Денефіль, Ю. Ю. Яриш // Здобутки клініч. і експерим. медицини. - 2018. - № 1 (33). - С. 109-114.

2. Алексевич К. О. Зміни показників біоенергетичних процесів за умов одночасного ураження щурів токсичними дозами адреналіну та тетрахлорметану / К. О. Алексевич, Л. С. Фіра, О. І. Грималюк // Здобутки клініч. і експерим. медицини. - 2015. - № 1 (22). С. 13-16.

3. Профрілактика серцево-судинних захворювань: чи завжди ми встигаємо? / І. В. Давидова, Н. А. Кожухарова, Л. І. Конопляник, Т. В. Сімагіна // Семейная медицина. - 2016. - № 6. - С. 20-24.

4. Коваленко В. М. Серцево-судинні хвороби: медично-соціальне значення та стратегія розвитку кардіології в Україні / В. М. Коваленко, А. П. Дорогой // Укр. кардіол. журн. - 2016. - Дод. 3. - С. 5-14.

5. Brydon L. Platelets, coronary heart disease, and stress / L. Brydon, K. Magid, A. Steptoe // Brain Behav. Immun. - 2006. - 20 (2). - P. 113-119.

6. Eisenmann E. D. Acute stress decreases but chronic stress increases myocardial sensitivity to ischemic injury in rodents / E. D. Eisenmann, B. R. Rorabaugh, P. R. Zoladz // Front. Psychiatry. - 2016. - 7. - P. 71.

7. Зміни показників перекисного окиснення ліпідів і антиоксидантної системи у внутрішніх органах щурів при дії кардіотоксичної дози адреналіну / О. В. Денефріль, М. О. Рябоконь, С. С. Рябоконь, Р. С. Усинський // Буковин. мед. вісн. - 2018. - 22 (88), № 4. - С. 20-26.

8. Lobo Filho H. G. Experimental model of myocardial infarction induced by isoproterenol in rats / H. G. Lobo Filho, N. L. Ferreira, R. B. Sousa // Rev. Bras. Cir. Cardiovasc. - 2011. - 3. - P. 232-237.

9. Метаболизм миокарда и препараты метаболического действия / В. М. Олесова, О. Ю. Маркатюк, Ю. Ю. Юрова, А. Г. Обрезан // Кардиология. - 2013. 53, № 1. - С. 66-71.

10. Фуштей И. М. Некоторые вопросы метаболической терапии при ишемической болезни сердца / И. М. Фуштей // Сучасні мед. технології. - 2010. № 3. - C. 111-116.
11. Аксьонова І. І. Перспективи застосування лікарських засобів рослинного походження у комплексній терапії атеросклерозу / I. І. Аксьонова, І. М. Білай // Актуальні питання фрармац. і мед. науки та практики. 2013. - № 2 (12). - C. 74-76.

12. Линда О. С. Дослідження мембранопротекторної активності сухого екстракту з хости ланцетолистої / О. С. Линда, Л. С. Фіра // Сучасні досягнення фрармацевтичної науки в створенні та стандартизації лікарських засобів і дієтичних добавок, що містять компоненти природного походження : матеріали I Міжнар. наук.-практ. Інтернет-конфр. (Харків, 5 квіт. 2018 р.). - Харків, 2018. - С. 82.

13. Процька В. В. Фармакогностичне дослідження хости подорожникової та хости ланцетолистої : дис. ... канд. фрармац. наук : 15.00.02 / Процька Вікторія Василівна. - Харків, 2017. - 224 с.

14. Хара М. Р. Гендерні та вікові особливості метаболізму міокарда за умов дії адреналіну та даларгіну / М. Р. Хара, Г. С. Сатурська, А. А. Лепявко // Наукові дослідження - теорія і експеримент 2008 : матеріали IV наук.-практ. конор., 19-21 трав. 2008 р. Полтава : Інтерграсріка, 2008. - 5. - С. 76-78.

15. Рыболовлев Ю. Р. Дозирование веществ для млекопитающих по константам биологической активности / Ю. Р. Рыболовлев, Р. С. Рыболовлев // Докл. AH CCCР. - 1979. - 247, № 6. - С. 1513-1516.

16. Мойбенко А. Патогенетическое обоснование эфффективности нового отечественного кардиопротектора корвитина (водорастворимого кверцетина) при остром инораркте миокарда / А. Мойбенко // Вісн. фрармакології та фрармації. - 2007. - № 5. - С. 38-47.

17. Влізло В. В. Лабораторні методи досліджень у біології, тваринництві та ветеринарній медицині : довідник / В. В. Влізло, Р. С. Федорук, І. Б. Ратич. Львів : Сполом, 2012. - 764 с.

18. Gross D. Ethics in Animal-Based Research / D. Gross, R. Tolba // Eur. Surg. Res. - 2015. - 55 (1). C. $43-57$.

19. Okeh U. Statistical problems in medical research / U. Okeh // East. Afr. J. Public. Health. - 2009. - 6 (1). P. 1-7.

20. Ghosh R. NSAIDs and Cardiovascular Diseases: Role of Reactive Oxygen Species / R. Ghosh, A. Alaj- 
begovic, A. V. Gomes // Oxid. Med. Cell Longev. - 2015. 2015. - P. 25.

21. Интенсивная терапия острого повреждения легких при тяжелых респираторных вирусных инорекциях / [И. П. Шлапак, О. А. Лоскутов, А. Н. Дружина и др.]. - К., 2011. - 136 c.

\section{REFERENCES}

1. Musiienko, A.M., Denefil, O.V., \& Yarysh, Yu.Yu. (2018). Zminy pokaznykiv elektrokardiohram pry adrenalinovo-kaltsiievii modeli urazhennia sertsia shchurivsamtsiv ta zastosuvanni z metoiu korektsii kvertsetynu [Changes of electrocardiogram indices in adrenalinecalcium model of lesion of male rats and use for quercetin correction]. Zdobutky klinichnoi i eksperymentalno medytsyny - Achievements of Clinical and Experimental Medicine, 1 (33), 109-114 [in Ukrainian].

2. Aleksevych, K.O., Fira, L.S., \& Hrymaliuk, O.I. (2015). Zminy pokaznykiv bioenerhetychnykh protsesiv za umov odnochasnoho urazhennia shchuriv toksychnymy dozamy adrenalinu ta tetrakhlormetanu [Changes in bioenergy processes in the context of simultaneous lesions of rats with toxic doses of adrenaline and tetrachloromethane]. Zdobutky klinichnoi i eksperymentalnoi medytsyny - Achievements of Clinical and Experimental Medicine, 1, 13-16 [in Ukrainian].

3. Davydova, I. V. (2016). Profilaktyka sertsevo-sudynnykh zakhvoriuvan: chy zavzhdy my vstyhaiemo [Prevention of cardiovascular disease: do we always have time]. Family Medicine - Semeynaya Meditsina, 6, 20-24 [in Ukrainian].

4. Kovalenko, V.M., \& Dorohoi, A.P. (2016). Sertsevosudynni khvoroby: medychno-sotsialne znachennia ta stratehiia rozvytku kardiolohii v Ukraini [Cardiovascular diseases: medical and social importance and strategy of cardiology development in Ukraine]. Ukrainskyi Kardiolohichnyi Zhurnal - Ukrainian Cardiology Journal, 3, 5-14 [in Ukrainian].

5. Brydon, L., \& Magid, K., \& Steptoe, A. (2006). Platelets, coronary heart disease, and stress Brain Behav. Immun., 20 (2), 113-119.

6. Eisenmann, E.D., Rorabaugh, B.R., \& Zoladz, P.R. (2016). Acute stress decreases but chronic stress increases myocardial sensitivity to ischemic injury in rodents. Frontiers in Psychiatry, 7, 71.

7. Denefil, O.V., Riabokon, M.O., Riabokon, S.S., \& Usynskyi, R.S. (2018). Zminy pokaznykiv perekysnoho okysnennia lipidiv i antyoksydantnoi systemy u vnutrishnikh orhanakh shchuriv pry dii kardiotoksychnoi dozy adrenalinu [Changes in lipid peroxidation and antioxidant system in rat internal organs under cardiotoxic dose of adrenaline]. Bukovynskyi medychnyi visnyk - Bukovyna Medical Bulletin, 22 (4), 20-26 [in Ukrainian].

8. Lobo Filho, H.G., Ferreira, N.L., \& Sousa, R.B. (2011). Experimental model of myocardial infarction induced by isoproterenol in rats. Rev. Bras. Cir. Cardiovasc., 3, 232-237.

9. Olesova, V.M., Markatiuk, O.I., Iurova, I.I., \& Obrezan, A.G. (2013). Metabolizm miokarda i preparaty
22. Sex Hormones and the QT Interval: A Review / T. Sedlak, C. Shufelt, C. Iribarren [et al.] // J. Womens Health (Larchmt). - 2012. - 21 (9). - P. 933-941.

23. Колиушко Г. И. Псевдокоронарные изменения ЭКГ (часть 1) / Г. И. Колиушко // Ліки України. - 2012. № 3-4 (1). - С. 50-57. metabolicheskogo deystviya [Myocardial metabolism and metabolic drugs]. Kardiologiya - Cardiology, 1, 66-71 [in Russian].

10. Fushtey, I.M. (2010). Nekotorye voprosy metabolicheskoy terapii pri ishemicheskoy bolezni serdtsa [Some issues of metabolic therapy for coronary heart disease]. Suchasni medychni tekhnolohii - Advanced Medical Technology, 3, 111-116 [in Russian].

11. Aksonova, I.I., \& Bilai, I.M. (2013). Perspektyvy vykorystannia likarskykh zasobiv roslynnoho pokhodzhennia u kompleksnii terapii aterosklerozu [Prospects for use of herbal medicines in the complex therapy of atherosclerosis]. Aktualni pytannia farmatsevtychnoi $i$ medychnoi nauky ta praktyky - Topical Issues of Pharmaceutical and Medical Science and Practice, 2, 74-76 [in Ukrainian].

12. Lynda, O.S., \& Fira, L.S. (2018). Doslidzhennia membranoprotektornoi aktyvnosti sukhoho ekstraktu z khosty lantsetolystoi [Investigation of membrane protector activity of dry extract from host lanceolate]. Suchasni dosiahnennia farmatsevtychnoi nauky $v$ stvorenni ta standartyzatsii likarskykh zasobiv i diietychnykh dobavok, shcho mistiat komponenty pryrodnoho pokhodzhennia: mat. I Mizhnarodnoi naukovo-praktychnoi Internet-konferentsii - Modern Achievements of Pharmaceutical Science in the Creation and Standardization of Medicines and Dietary Supplements Containing Components of Natural Origin: Materials of I International Scientific-practical Internet-conference (p. 82). Kharkiv [in Ukrainian].

13. Protska, V.V. (2017). Farmakohnostychne doslidzhennia khosty podorozhnykovoi ta khosty lantsetolystoi [Pharmacognostic study of plantain hosts and lanceolate hosts]. Candidate's thesis. Kharkiv [in Russian].

14. Khara, M.R., Saturska, H.S., \& Lepiavko, A.A. (2008). Henderni ta vikovi osoblyvosti metabolizmu miokarda za umov dii adrenalinu ta dalarhinu [Gender and age-specific features of myocardial metabolism under adrenaline and dalargin]. Naukovi doslidzhennia - teoriia i eksperyment 2008: materialy IV nauk.-prakt. konf., 1921 travnia 2008 r. - Scientific Research - Theory and Experiment 2008: Materials of IV Scientific Practice. Conf., May 19-21, 2008 (pp. 76-78). Poltava: Interhrafika [in Ukrainian].

15. Rybolovlev, Yu.R., \& Rybolovlev, R.S. (1979). Dozirovanie veshchestv dlya mlekopitayushchikh po konstantam biologicheskoy aktivnosti [Dosing of substances for mammals according to biological activity constants]. Doklady AN SSSR - Reports of the USSR Academy of Sciences, 247 (6), 1513-1516 [in Russian].

16. Moibenko, A. (2007). Patogeneticheskoe obosnovanie effektivnosti novogo otechestvennogo 
kardioprotektora korvitina (vodorastvorimogo kvertsetina) pri ostrom infarkte miokarda [Pathogenetic substantiation of the effectiveness of a new domestic cardioprotector corvitin (water-soluble quercetin) in acute myocardial infarction]. Visnyk farmakolohii ta farmatsii - Bulletin of Pharmacology and Pharmacy, 5, 38-47 [in Russian].

17. Vlizlo, V.V., Fedoruk, R.S., \& Ratych, I.B. (2012). Laboratorni metody doslidzhen u biolohii, tvarynnytstvi ta veterynarnii medytsyni: dovidnyk [Laboratory research methods in biology, animal husbandry and veterinary medicine: a handbook]. Lviv: SPOLOM [in Ukrainian].

18. Gross, D., \& Tolba, R.H. (2015). Ethics in animalbased research. European Surgical Research, 55 (1-2), 43-57.

19. Okeh, U. (2009). Statistical problems in medical research. East African Journal of Public Health, 6 (3), 1-7.
20. Ghosh, R., Alajbegovic, A., \& Gomes, A. V. (2015). NSAIDs and cardiovascular diseases: Role of reactive oxygen species. Oxidative Medicine and Cellular Longevity, 2015, 1-25.

21. Shlapak, I.P., Loskutov, O.A., Druzhina, A.N., Pilipenko, M.N., \& Todurov, B.M. (2011). Intensivnaya terapiya ostrogo povrezhdeniya legkikh pri tyazhelykh respiratornykh virusnykh infektsiyakh [Intensive care for acute lung injury in severe respiratory viral infections]. Kyiv: Department of Anesthesiology and Intensive Care NMAPE named after P.L. Shupyk [in Russian].

22. Sedlak, T., Shufelt, C., Iribarren, C., \& Merz, C.N.B. (2012). Sex hormones and the QT interval: A review. Journal of Women's Health, 21 (9), 933-941.

23. Kolyushko, G.I. (2012). Psevdokoronarnye izmeneniya EKG (chast 1) [Pseudocoronary ECG changes (part 1)]. Liky Ukrainy - Medicines of Ukraine, 3-4 (1), 50-57 [in Russian].

\section{СРАВНИТЕЛЬНЫЙ АНАЛИЗ КАРДИОПРОТЕКТОРНЫХ СВОЙСТВ КОРВИТИНА И СУХОГО ЭКСТРАКТА ИЗ ХОСТЫ ЛАНЦЕТОЛИСТНОЙ ЛИСТЬЕВ ПРИ АДРЕНАЛИНОВОМ ПОВРЕЖДЕНИИ СЕРДЦА}

\section{Резюме}

Вступление. В современных условиях психоэмоциональный стресс осложняет течение и прогноз основных заболеваний сердечно-сосудистой системы (ишемической болезни сердца, инфаркта миокарда, гипертонической болезни, атеросклероза) и может привести к развитию некротического повреждения миокарда. Исследования, которые проводят в последние годы фрармакологи, фрармацевты и медики, направлены на поиск новых растительных средств с кардиопротекторными свойствами с большей эфрфективностью и меньшей токсичностью по сравнению с существующими на сегодня на фрармацевтическом рынке препаратами.

Цель исследования - изучить мембранопротекторные свойства сухого экстракта из хосты ланцетолистной листьев и показатели фрункционирования сердечной мышцы на модели токсического поражения сердца адреналином.

Методы исследования. Эксперименты проведены на шестимесячных 42 белых крысах-самцах массой 180-200 г. Некротическое повреждение миокарда моделировали путем однократного внутримышечного введения 0,18 \% раствора адреналина гидротартрата из расчета 0,5 мг/кг. С целью коррекции ежедневно в течение эксперимента вводили сухой экстракт из хосты ланцетолистной листьев в дозе 100 мг/кг массы тела и корвитин в дозе 42 мг/ке. Исследование выполняли через 24 и 48 ч после введения адреналина. Записывали и проводили анализ электрокардиограмм, в сыворотке крови и сердце определяли активность аспартатаминотрансореразы и креатинфоссрокиназы.

Результаты и обсуждение. Активность аспартатаминотрансферазы и креатининфофсокиназы в сыворотке крови крыс, которым вводили адреналин, повышалась во все сроки эксперимента. Активность креатининфосфокиназы в сыворотке крови животных после введения адреналина увеличивалась: через 24 ч - в 2,2 раза, через 48 ч - в 2,5 раза. В сердце крыс наблюдали обратную тенденцию к снижению этих показателей. Через 24 ч после введения адреналина положительное влияние на активность энзимов имел корвитин. В конце эксперимента эфрфективными оказались оба корригирующих фрактора. На электрокардиограммах подтверждено развитие миокардиодистрофрии у крыс, получивших токсическую дозу адреналина. К концу эксперимента как экстракт, так и корвитин проявили положительное влияние на показатели электрокардиограммы у животных, что подтвердило их кардиопротекторные свойства. 
Выводы. Кардиотоксическая доза адреналина приводит к цитолизу кардиоцитов и изменению проницаемости плазматических мембран, на что указывают повышение активности аспартатаминотрансореразы и креатынинфоосфокиназы в сыворотке крови и ее снижение в сердче. Сухой экстракт из хосты ланцетолистной листьев и корвитин имеют выраженное протекторное влияние на активность энзимов. Экстракт и корвитин, которые введены на фроне адреналинового повреждения сердца, уменьшают возбудимость синусового узла и замедляют проведение импульсов предсердиями и желудочками.

КЛЮЧЕВЫЕ СЛОВА: адреналин; сухой экстракт из хосты ланцелистной листьев; корвитин; белые крысы.

O. S. Lynda, V. Ye. Pelykh, L. S. Fira, O. V. Denefil I. HORBACHEVSKY TERNOPIL NATIONAL MEDICAL UNIVERSITY

\section{A COMPARATIVE ANALYSIS OF THE CARDIOPROTECTIVE PROPERTIES OF CORVITIN AND DRY EXTRACT FROM THE LANCEOLATE HOSTA LEAVES AT ADRENALINE HEART INJURY}

\section{Summary}

Introduction. In modern conditions, psycho-emotional stress complicates the course and prognosis of major diseases of the cardiovascular system (coronary heart disease, myocardial infarction, hypertension, atherosclerosis) and can lead to the development of necrotic damage to the myocardium. Studies conducted in recent years by pharmacologists, pharmacists and physicians aimed at finding new herbal remedies with cardioprotective properties with greater efficacy and less toxicity than those currently available in the pharmaceutical market.

The aim of the study - to learn the membrane-protective properties of the dry extract of the hosta lanceolate leaves and indicators of the functioning of the heart in a model of toxic heart damage by adrenaline.

Research Methods. The experiments were performed on 42 white male rats 6 months old of 180-200 g. Necrotic myocardial damage was modeled by a single intramuscular injection of $0.18 \%$ adrenaline hydrotartrate solution at the rate of $0.5 \mathrm{mg} / \mathrm{kg}$. For the purpose of correction, a dry extract was injected daily from the hosta of the lanceolate leaves at a dose of $100 \mathrm{mg} / \mathrm{kg}$ body weight and corvitin at a dose of $42 \mathrm{mg} / \mathrm{kg}$ daily during the experiment. The study was performed 24 and 48 hours after the administration of adrenaline. Electrocardiograms were recorded and analyzed, and the activity of aspartate aminotransferase and creatine phosphokinase was determined in blood serum and heart.

Results and Discussion. The activity of aspartate aminotransferase and creatine phosphofokinase in the blood serum of rats treated with adrenaline increased throughout the duration of the experiment. The activity of creatine phosphokinase in the blood serum of animals after administration of adrenaline increased: after 24 hours - 2.2 times, after 48 hours -2.5 times. In the heart of rats, an inverse tendency to a decrease in these indicators was observed. 24 hours after the administration of adrenaline, Corvitin had a positive effect on the activity of enzymes. At the end of the experiment, both corrective factors were effective. Electrocardiograms confirmed the development of myocardial dystrophy in rats that received a toxic dose of adrenaline. By the end of the experiment, both the extract and corvitin showed a positive effect on the electrocardiogram indices in animals, which confirmed their cardioprotective properties.

Conclusions. A cardiotoxic dose of adrenaline leads to cytolysis of cardiocytes and a change in the permeability of plasma membranes, as indicated by an increase in the activity of aspartate aminotransferase and creatine phosphokinase in blood serum and its decrease in the heart. The dry extract of the hosta of the lanceolate leaves and corvitin have a pronounced protective effect on the activity of enzymes. The extract and corvitin, which are introduced against the background of adrenaline damage to the heart, reduce the excitability of the sinus node and decrease the conduction of impulses in the atria and ventricles.

KEY WORDS: adrenaline; hosta leaf dry extract; corvitin; white rats.

Адреса для листування: Л. С. Фіра, Тернопільський національний медичний університет імені І. Я. Горбачевського МОз України, майдан Волі, 1, Тернопіль, 46001, Україна, e-mail: firals@tdmu.edu.ua. 